\title{
Community Risk Management by Mining MNEs Managing Local Communities in Armenian Mining
}

Taarup-Esbensen, Jacob; Movsisyan, Suren

Document Version

Accepted author manuscript

Published in:

International Journal of Business and Globalisation

DOI:

10.1504/IJBG.2019.10022554

Publication date:

2019

License

Unspecified

Citation for published version (APA):

Taarup-Esbensen, J., \& Movsisyan, S. (2019). Community Risk Management by Mining MNEs: Managing Local Communities in Armenian Mining. International Journal of Business and Globalisation, 23(1), 120-138.

https://doi.org/10.1504/IJBG.2019.10022554

Link to publication in CBS Research Portal

\section{General rights}

Copyright and moral rights for the publications made accessible in the public portal are retained by the authors and/or other copyright owners and it is a condition of accessing publications that users recognise and abide by the legal requirements associated with these rights.

Take down policy

If you believe that this document breaches copyright please contact us (research.lib@cbs.dk) providing details, and we will remove access to the work immediately and investigate your claim. 


\section{Community Risk Management by Mining MNEs: Managing Local Communities in Armenian Mining Jacob Taarup-Esbensen and Suren Mousisyan}

Journal article (Accepted manuscript*)

\section{Please cite this article as:}

Taarup-Esbensen, J., \& Movsisyan, S. (2019). Community Risk Management by Mining MNEs: Managing Local

Communities in Armenian Mining. International Journal of Business and Globalisation, 23(1), 120-138. https://doi.org/10.1504/JJBG.2019.10022554

DOl: https://doi.org/10.1504//JBG.2019.10022554

* This version of the article has been accepted for publication and undergone full peer review but has not been through the copyediting, typesetting, pagination and proofreading process, which may lead to differences between this version and the publisher's final version AKA Version of Record.

Uploaded to CBS Research Portal: August २०२० 


\title{
Community risk management by mining MNEs: managing local communities in Armenian mining
}

\author{
Jacob Taarup-Esbensen*
}

Zealand Institute of Business and Technology and

Copenhagen Business School, Denmark

Email: Jta.msc@cbs.dk

*Corresponding author

\section{Suren Movsisyan}

Department of Economics, Armenian National Agrarian University, 74 Teryan Street, 0009, Yerevan, Armenia Email: suren@movsisyan.dk

\begin{abstract}
Using field work from the Armenian mining sector, we explore how MNEs practice community risk management. We start by conceptualising communities as communities of place (CofP), directly impacted by mining activities but have few resources, and communities of interest (CofI), as outsiders with an interest in mining projects and the resources to create uncertainty about the mine. We argue that community risk is a precursor to financial, political and cultural risks and that both CofP and CofI can expose the mining MNE to risks, either individually or in unison. We find that mining MNEs focus on mitigating community risks in the initial phases of the mine project, when the impact on the CofP is perceived to be lowest. Our interpretation is that the objective of the risk management practice is to commit resources to CofP for as long as there is a possibility that they will form partnerships with CofI.
\end{abstract}

Keywords: community risk; mining MNE; risk management; Armenia; liability of outsidership; communities of place; CofP; communities of interest; CofI.

Reference to this paper should be made as follows: Taarup-Esbensen, J. and Movsisyan, S. (xxxx) 'Community risk management by mining MNEs: managing local communities in Armenian mining', Int. J. Business and Globalisation, Vol. X, No. Y, pp.xxx-xxx.

Biographical notes: Jacob Taarup-Esbensen does his research at the Copenhagen Business School (CBS) and at Zealand Institute of Business and Technology where he is an Assistant Professor. He has a research background in management within the field of risk management, corporate social responsibility and quality assurance within infrastructure projects such as mining and renewable energy in the Caucasus.

Suren Movsisyan received his $\mathrm{PhD}$ in Economics at the Armenian National Agrarian University. He has a background in mining and renewable energy (i.e., wind turbines, global wind atlas of Danish Technical University), financial management, accounting, risk management, marketing, digital marketing, IT, alcohol beverages' industry, insurance, augmented reality, 
virtual reality, lidar, UAV, cooperatives. He is currently an IT and Marketing Account Manager in Incredo, which was ranked by Clutch as the world's top 6 digital marketing agency. He is an author of 15 scientific papers and co-author of a book, which are published and cited in 17 countries.

\section{Introduction}

The ability of firms operating internationally to evaluate the chance of loss or to identify an opportunity is central to its survival and future prosperity (Figueira-de-Lemos et al., 2011; Ghoshal, 1987; Hagigi and Sivakumar, 2009; Power, 2004). The multinational enterprise (MNE) interacts and balances between multiple stakeholder constituencies across multiple geographical locations and the more diverse the business environment, the more numerous the interests and relationships that need to be managed. Few business environments represent such complexity and difficulty to manage than those originating from local communities in connection with mining projects (BSR, 2003; Franks et al., 2014; Graetz and Franks, 2015; Prno and Slocombe, 2014). In the last decade, the management of risks from local communities has been increasingly important, as the influence of these groups has increased, first, because they have gained the ability to communicate with a wider national or even global audience through new communication technologies, and second, because civil society actors such as social and environmental non-governmental organisations (NGOs) use local community support in order to leverage their own claims against mining activities (Bebbingtion et al., 2008; Dana et al., 2009; Holterman, 2014). While it is well documented how mining projects is affecting communities, it is to a lesser degree researched how mining companies are mitigating risk events from these types of stakeholders. To differentiate between different forms of communities, this paper refers to local communities as communities of place (CofP), indicating their geographical closeness to the mining MNE's place of operation, while NGOs and other civil society actors are referred to as communities of interest (CofI), being outsiders but having an interest in the activities of the mining MNE (Calvano, 2008; Selmier et al., 2015). Risks from CofP can take many forms, but the common denominator is that they originate from villages and towns near the MNE's place of operation, and their epicentre is the community's concerns about their future when subjected to changes induced by the MNE's activities (Calvano, 2008; Horowitz, 2010; Miller and Lassard, 2001; Perri, 2005; Stoffle and Minnis, 2008).

The MNE is at a disadvantage compared to local companies when it comes to mitigating community risks (Gifford and Kestler, 2008; Johanson and Vahlne, 2009). It has little practical knowledge about the local political, social and cultural context and thus needs to learn what is deemed important to the community, and, because of increased efficiency of communication, there can be little time for the MNE to react and mitigate events when risks first materialise. This puts pressure on the mining MNE to implement effective risk management practices that will reduce the chance that projects could be terminated or significantly changed, as this could increase costs significantly.

One of the places where community risks are dominant is in the mining industry, where the social and environmental impact and changes to CofP are often very noticeable (BSR, 2003; Kemp et al., 2016; Miller and Lassard, 2001). Through multiple case studies in Armenia, where mining operations have been conducted for several centuries, it is 
possible to gain valuable lessons on the changes that CofP go through and the mechanisms that guide the practices of community risk management. During the Soviet period, mining production was expanded vigorously to recover the union's weak economy after World War II, and today the mining industry continues to be the largest contributor to the Armenian economy (Bond and Levine, 1997). As of 2011, the mining sector had more than 600 operating mines, including 27 base metal mines, which is quite significant in a country of only around $29,000 \mathrm{~km}^{2}$ (Investment Guide, 2013). Active MNEs in Armenian mining include nine foreign-owned companies, all involved in metal extraction, e.g., gold, copper-molybdenum, silver and iron. The export of ore is estimated to account for a significant part (around 30\%) of the Armenian economy and, according to the mining contribution index (ICMM, 2014; The Economist, 2015), is the country heavily reliant on the industry. The importance of mining makes the MNEs a focus of attention from government officials, politicians, NGOs and a wide range of other stakeholders who have an interest in the impact of mining on Armenian society and especially on CofPs close to mining sites. It is well documented in the literature how these communities are impacted and changed by mining activities (Dana and Anderson, 2014; Gifford and Kestler, 2008; Kemp and Owen, 2013) - for example, in the form of socioeconomic impacts that occur as a result of community members starting to work at the mine, often at higher wages than the average pay, when the effect of pollution becomes apparent, affecting community members and livestock (Anderson, 2014; Petrosyan et al., 2004), or when the infrastructure of the village or city undergoes changes as the MNE builds or renovates roads, gas pipes and electricity networks [Morris et al., (2012), p.143].

The social and physical impact of a mining project does not all happen at once but rather in small incremental steps as the project unfolds (Kraemer and van Tulder, 2009; Lynch, 2002). In the initial phases, the changes might be in the form of visits from surveyors and community meetings about the project, while later on, and as the scale of activities expands, the impact becomes more tangible in the form of changes to infrastructure, landscape, economic status and environment. In the initial phases of the project, the impact on the community is small, as there is little or no change to the social and economic life of the community. As the project matures and activities expand, however, so do the changes that the local community has to endure, such as long-term health issues and pollution as well as changes to the local social and economic structures.

Given that CofP can pose a potential threat to business continuity, the paper explores the community risk management practices of mining MNEs and asks the question: how is community risk management practised by mining MNEs in Armenia?

We seek to answer the research question through a multiple case study of mining MNEs operating in Armenia, based on desk research, interviews and fieldwork observations. First, the risk management practice is conceptualised through a review of the MNE management literature and the development of a model for community risk management. The model is then used to analyse how mining MNEs in the country manage community risk and the practices they utilise to mitigate this type of uncertainty. Based on the findings, we answer the research question and present a revised model, thereby contributing to the MNE risk management literature with knowledge about community risk management practices. 


\section{Theory: an MNE perspective on community risk}

The MNE risk management literature describes three types of uncertainty associated with foreign direct investments, namely financial, political and cultural risks [Feinberg and Gupta, 2009; Gifford and Kestler, 2008; Lundan, (2014), p.337f; Miller, 1992]. Economic uncertainties or financial risks come in the form of currency exchange risks, such as equity market fluctuations, commodity prices and host and home country interest rates [Birt et al., 2013; Christoffersen, (2003), p.5]. Political risks are the arbitrary actions of governments concerning investment projects, including outright expropriation, the seizing of operations, forced contract renegotiations and acts of political violence or regulatory interference (Erb et al., 1996; Simon, 1984). Cultural risks originate from differences in an MNE's perception of its decisions and that of its stakeholders, which impacts historical, religious, social or cultural norms (Franks and Cohen, 2012; Graetz and Franks, 2015; Kemp and Owen, 2013; Lodh and Nandy, 2008). For these types of risk to emerge, a certain level of formalisation needs to be reached that can actually subject the MNE to risk - for example, political risks will emerge only when political actors are involved and financial risks when doubts emerge among lenders and investors about the MNEs ability to fulfil its financial commitments (Bekaert et al., 2014; Boddewyn and Brewer, 1994; Erb et al., 1996). In order for communities to pose a risk, they therefore need to apply their resources in such a way that it subjects the MNE to a risk that is perceived as real. CofPs might not have this formalisation, as the community is too small in numbers or has too few resources available to it to pose a credible risk. It is therefore possible that risks from CofPs arise when they partner with other organisations that have a higher level of formalisation, as when the CofP is represented by NGOs, the media, politicians or religious representatives (BSR, 2003; ICMM, 2015). These organisations can make claims on behalf of the community and thereby engender community risks that can elicit responses from financial, political and cultural actors. Examples of these types of risks materialising can be seen in multiple case studies from all over the world from the impact of extractives project development in Canada (Dana et al., 2009; Kadenic, 2015) to small-scale mining in sub-Saharan Africa (Hilson and McQuilken, 2014; Nyame and Grant, 2014) and sometimes a troublesome relationship with aboriginals in Australia (Cheshire, 2010; O'Fairchellaigh, 2003). However, as the number of stakeholders and possible different financial, political and cultural risks increase, so does the complexity the MNE faces. It is therefore in the interests of the MNE to identify community risks at an early stage and, if possible, before this formalisation takes place, in order to initiate mitigation efforts that will, for example, prevent governmental intervention (political risk), lead to loss of the social licence to operate (cultural risk) or cause investors to increase interest rates or make other demands that affect cost structures (financial risk).

The MNE is at a unique disadvantage when it comes to managing its CofP risks. MNEs are subjected to liability of outsidership and internationalisation itself, involving a process of timely and incremental learning processes, being an outsider to the national and cultural context (Johanson and Vahlne, 2009; Selmier et al., 2015; Zaheer, 1995). Over time, the firm becomes more knowledgeable about the local conditions and how to handle the CofP in the areas where it operates, but this process takes time and requires resources. However, with access to communication technologies and increased interest from both investors and political and cultural actors, this time is not necessarily available to the MNE. The complex environment means that MNEs are simultaneously in the 
process of learning about their community impact, which requires an in-situ presence, and having to make decisions that undoubtedly will affect the community of place. With the aim of handling this continuous process, the organisation tries to learn from other similar MNEs by mimicking or copying their risk management systems in the hope that this will stimulate its learning process (DiMaggio and Powell, 1983) - for example, in the form of stakeholder engagement or corporate social responsibility programmes (Park et al., 2014; Selmier et al., 2015; Tatoglu, et al., 2013). By using such systems, the MNE structures its approach in line with recognised international standards as well as increases the speed at which knowledge is acquired about its impact as a result of inconsistencies between the performance of the MNE and the expectations of salient stakeholder groups.

Community risk is conceptualised by considering the uncertainties arising from these actors as risks that lack the structure and formalisation that traditional risk management systems are designed to identify. To understand community risks, we draw on a sociological understanding of the tension between certainty and uncertainty, or the known and unknown, as the actors perceive it (Burgess, 2015; Power, 2004, 2007). Perceived risk expands the notion of the social and physical environments as complex systems that provide risk managers and stakeholders with different representations of what is real, i.e., what constitutes risk and what does not. This perception of risk is thus considered as part of how individual community members make sense of the uncertainties that come from changes in their environment and the actions that they take to mitigate these. Hence, community risk stems from how these actions can possibly influence business continuity.

This conceptualisation of community risk comes with several implications. It enables different perceptions of the same event, as differences arise between how actions taken by the MNE and the CofP should be interpreted. Second, perception can give rise to actions by the CofP that are not necessarily founded on objectively observable facts but rather on their interpretation of changes and events in their social and physical environment (Canabal and White, 2008; Graetz and Franks, 2015; Missens et al., 2007; Prno and Slocombe, 2014). Furthermore, for the CofP to pose a risk to the MNE, it needs to take some form of action (invest its resources) in such a way that it poses a possible threat to the MNE. The resources can come from the CofP itself, or the MNE can draw on the resources from CofIs and, hence, pose financial, political or cultural risks to the MNE. The concept of community risk management is therefore defined as the ability of the MNE to identify community perceptions and implement practices that enable them to gain the acceptance of the CofP. Community risks do not need to originate from a physical change in the local environment but could potentially have their roots in the aspirations and the expectations the community has of corporate behaviour.

A review of the MNE risk management literature and the conceptualisation of community risk outline the basis of a model describing community risk management as practised by mining MNEs. The model (Figure 1) consists of four elements: the mining MNE, risks, CofP and CofI. The model describes the mining MNE as an organisation that can be subject to risk in the form of financial, political and cultural uncertainties and that controls these risks through its risk management practices. The uncertainties and risk originate from CofP, which can utilise its resources and therefore subject the MNE to risks, either directly or by partnering with CofI. What remains unknown is what the risk management practices of the mining MNE are, how communities apply their resources and the relationship between CofP and CofI. 
Figure 1 Model MNE risk management based on the literature (see online version for colours)

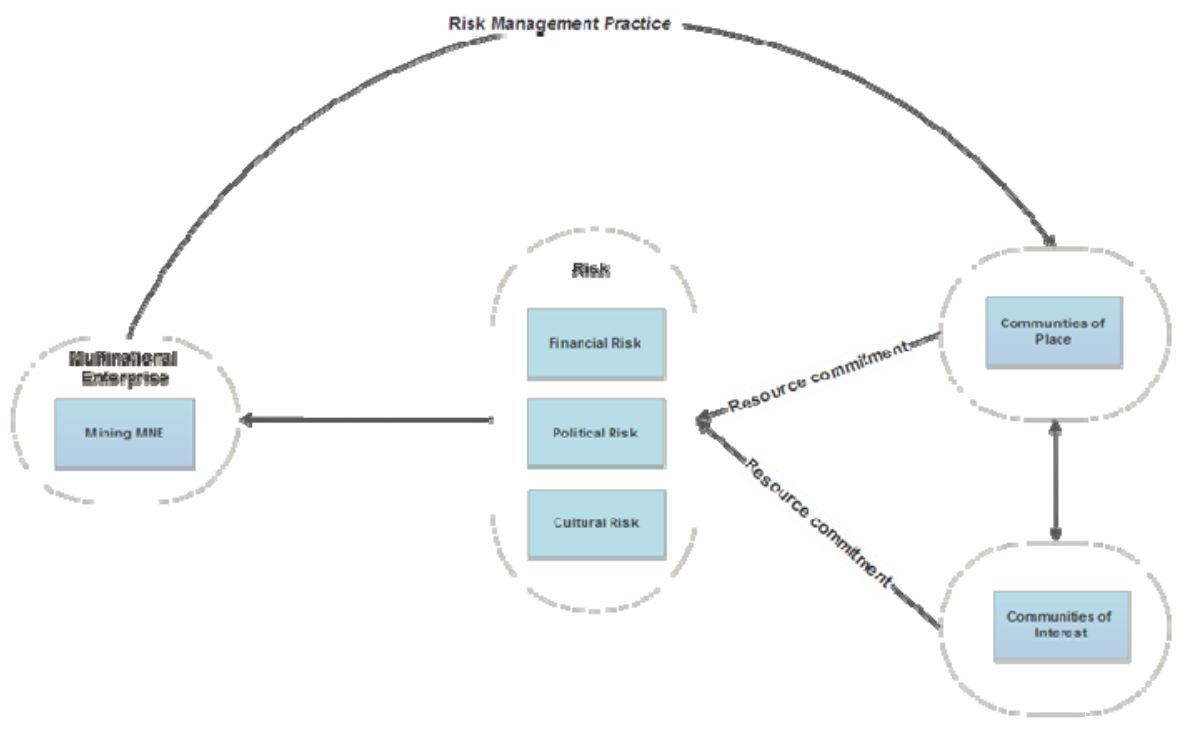

\section{Method}

The research is carried out as a multiple case study (Eisenhardt, 1989; Yin, 1994) of the Armenian mining industry, which includes all the mining MNEs that are currently active in Armenia. The multiple case study is used to provide an analytical depth that is needed when testing mining MNE community risk management practices and resource commitment of CofP and CofI. The case study approach follows similar research designs, where investigations have been made into the relationship between communities and business enterprises within the extractive industry (Dana et al., 2009; Graetz and Franks, 2015; Nyame and Grant, 2014). The choice of method was based on a review of research methods carried out on the mining industry and community relations in other places of the world, where interviews and field observations were the primary source of empirical evidence (For example, see Anderson, 2014; Cheshire, 2010; Dana and Anderson, 2014; Davis and Franks, 2014; Horowitz, 2010; Kemp and Owen, 2013).

We chose to approach the research through a deductive design where a pre-defined theoretical framework is developed by a review of the relevant literature and subsequently tested through observations and interviews (Dana and Dana, 2005; Dana and Dumez, 2015). Hence, we used the literature review to construct a model, described above, which subsequently could be tested in the field through interviews and fieldwork observations. Firstly, an initial desk screening was conducted that revealed the individual mining MNEs' home country ownership, the type of exploration, the location and presence of nearby communities and the number of years the mine had been active. This process included publicly available information from corporate websites, newspapers and annual reports (see Table 1). Based on this information, 14 exploratory interviews were conducted a year before the study to ensure that we had access to mining MNEs and villages affected by mining activities as well as to refine the final interview guide. 
Table 1 Cases of mining MNE and CofP

\begin{tabular}{lcccc}
\hline $\begin{array}{l}\text { Multinational } \\
\text { enterprise }(M N E)\end{array}$ & $\begin{array}{c}\text { Home } \\
\text { country }\end{array}$ & Exploration & Community of place & $\begin{array}{c}\text { Age of } \\
\text { mining site }\end{array}$ \\
\hline Vallex mining & Cyprus & Copper/molybdenum & Teghut, Shnogh & 1 year \\
$\begin{array}{l}\text { Lydian } \\
\text { International }\end{array}$ & Canada & Gold & $\begin{array}{c}\text { Vayots Dzor, } \\
\text { Saravan and Gndevaz }\end{array}$ & 0 years \\
Cronimet & Germany & Copper/Molybdenum & Kajaran & $25+$ years \\
$\begin{array}{l}\text { Dundee Precious } \\
\text { Metals }\end{array}$ & Canada & Gold & Kapan & $25+$ years \\
Fortune Oil & China & Iron & Hrazdan & 0 years \\
Global Gold & USA & Gold & Marjan, Toukhmanuk & $10+$ years \\
GeoProMining & Russia & Copper/Molybdenum & Agarak & $25+$ years \\
Orogen & UK & Gold & Mutsk & 5 years \\
Unity Gold & Ireland & Gold & Vayk & $25+$ years \\
\hline
\end{tabular}

Secondly, following the initial screening and explorative interviews were formal interviews conducted at five of the mining sites and 13 villages, which included representatives from CofP, MNE managers. Interviews were also carried out with representatives from CofI and investors situated in the capital, Yerevan, totalling 36 individual interviews. All interviews were semi-structured to allow for new information to come forward, which the initial screening of the literature and explorative interviews had not unveiled. Hence, the final interview guide related to MNE risk management and well-known consequences of mining on CofP, along with input from the initial exploratory interviews. The questions were organised thematically under culture and society, economics, environment, politics and governance, and the process of change itself as major themes identified in the literature. All interviews were transcribed to compare respondents answering the same questions. The data were coded by themes and sub-themes (Flick, 2009), corresponding to the way that respondents perceived how the mining MNE's activities affected the CofP. This methodological approach made it possible to identify causal powers that determined how mining MNEs and CofPs perceived a project's impact on the community as well as facilitating a detailed understanding of how the mining project had influenced the social dynamics of the CofP, economic development, effect of pollution, local politics and the management of community grievances.

In order to understand community risk management practice, we identified mechanisms that determined mining MNEs' decisions impacting the CofP and how these communities came to make decisions that could affect the mining MNEs' business continuity. Mechanisms are defined as plausible explanations (causal powers) for how changes in the social and physical world occur [Archer, 2010; Elder-Vass, (2010), p.43] in this instance, mining MNEs' community risk management practices and the resource commitment of communities. This critical realist stance allows for the observation of objectively identifiable facts about the world around us but also that people can have a different perception of these. Thereby, it is possible to observe both the decision-making process as well as concrete actions taken, by all the actors that contribute to increases or decreases in community risk. The research is in this way focused on identifying risks to 
the MNE that stem from the actions of CofP and CofI, with the understanding that it is not necessarily the objectively identifiable facts that cause communities to act but possibly a combination of different social and physical factors. Rather, it is the perception of the danger they are in and their subsequent decision to take actions on this perception that determine the level of threat to business continuity.

By using the same interview guide in all interviews and asking the same questions to CofP, CofI and representatives of the mining MNE, it was possible to compare responses; we were thereby able to identify differences in perceptions of how a given impact had been perceived by all involved. If the impact had materialised as a risk to MNE business continuity within any of the three risk types identified in the literature review (financial, political or cultural), it was characterised as a community risk event. If the possible risk event did not materialise, despite being impacted by the MNE, we investigated whether the CofP had declined to utilise its resources to affect business continuity and, thereby, in reality had accepted the negative impact of the mining project and, conversely, whether it had taken active steps against CofIs opposing the mining project, with the aim of disrupting the possible influence of civil society actors on the project. In this case, the result was interpreted as the CofP took the side of the mining project and deemed its impact as more positive than negative on the development of the CofP.

Beginning with the model and the theoretical review, there are four different outcomes when mining MNE activities impact CofP (summarised in Table 2). The four-by-four matrix is organised as follows: the axis on the left describes the CofP as either active (investing its own resources) or passive (not investing its own resources), while the top axis describes community risks as being increased or decreased. Community risks can be increased if the CofP commits its own resources and thereby poses a risk to the MNE (first quadrant), or it can partner with CofI, which then commits its own resources (second quadrant). Both situations would result in the possible realisation of risk, as resources are committed and aimed at triggering a response from financial, political or cultural actors. Community risk is decreased when the CofP either supports the mining MNE against the resource commitment of CofI (third quadrant) or accepts the impact of mining on the community (fourth quadrant). The CofI can choose to commit its resources against the MNE, but it would in this case be without the support of CofP, and hence, there is no community risk.

Table 2 Mining MNE impact on CofP

\begin{tabular}{|c|c|c|c|c|c|}
\hline \multirow[b]{2}{*}{$\begin{array}{l}\text { Mining MNE impact on } \\
\text { communities of place }\end{array}$} & \multirow[b]{2}{*}{$\begin{array}{l}\text { CofP as } \\
\text { active }\end{array}$} & \multirow[b]{2}{*}{1} & \multirow{2}{*}{$\begin{array}{c}\begin{array}{c}\text { Community risk } \\
\text { increased }\end{array} \\
\begin{array}{c}\text { CofP commits } \\
\text { resources }\end{array}\end{array}$} & \multicolumn{2}{|c|}{ Community risk decreased } \\
\hline & & & & 3 & $\begin{array}{l}\text { CofP supports the } \\
\text { mining MNE against } \\
\text { the CofI }\end{array}$ \\
\hline & $\begin{array}{l}\text { CofP as } \\
\text { passive }\end{array}$ & 2 & $\begin{array}{l}\text { CofP partners with } \\
\text { CofI, which then } \\
\text { commits resources }\end{array}$ & 4 & $\begin{array}{l}\text { CofP accepts the } \\
\text { impact }\end{array}$ \\
\hline
\end{tabular}

\section{Community risk - mining MNE impact on CofP}

The following is an account of the findings uncovered through fieldwork and interviews with CofP, MNE managers, CofI and investors. The section is organised as per the 
two-by-two matrix described above and discussed to illustrate each of the quadrants, in turn given examples from mining MNEs operating in Armenia.

\subsection{CofP commits resources}

It was claimed that a member of the Teghut CofP was beaten up by corporate security staff from the vallex group MNE, because he had raised dust by careless driving, something the local villagers claimed the company did all the time. As a result, the villagers blockaded the road to the mine, thereby hindering employees, usually transported to the site on buses, from getting to work. The people of Teghut wanted the mayor and regional governor to intervene and ensure local justice by making the MNE security staff change their behaviour and reduce the level of dust to which the community was subjected: "it is not enough that they [company's representatives] keep us in [mining] dust the whole time, and we do not say anything. One good man accidentally raised dust, and they caught our villagers and beat them in the centre of the village (interview, Teghut)". The event further evolved into a blockade, thereby escalating the incident. "Since early morning, residents of Teghut have blocked the road, and the workers, who come from nearby villages to work there, could not manage to enter the territory". The mayor of Teghut got involved, criticising the vallex group for using force, beating up community members and not being able to resolve the issue peacefully, saying, "vallex implemented rude power and forced the local villagers to settle the demonstration". The case illustrates how the CofP commits resources with the aim of applying pressure to the mining MNE, calling for the intervention of regional and national politicians by preventing the continued operation of the mine. The risk mitigation response from the mining $\mathrm{MNE}$ is, in this instance, to use force and thereby retain business continuity that otherwise would have been disrupted.

\subsection{CofP partners with CofI}

Kajaran, a town in the southern part of the country, had been affected by mining since the Soviet era and was less reluctant to engage the company, directly naming the mining MNE 'Cronimet, the aorta of Kajaran' (interview, Kajaran), even though the mayor acknowledged that the impact of having mining activities in the centre of the city caused "specific mining related diseases [...] as a result, there would be vivid changes in the genes for generations". Acknowledging that the negative impact was salient, there was awareness that the city, at this time, was reliant on the mine, where $80 \%$ of the population worked. Kajaran, being almost exclusively reliant on the mine, made the CofP less inclined to commit its own resources to raising risks for the mining MNE. However, by partnering with CofI and thereby utilising their resources, the CofP was less vulnerable and exposed, should the mining MNE decide to retaliate. In this case, the pan-Armenian environmental front, under the headline 'Armenia's breaking backbone', launched a campaign against the mine in Kajaran and against the firm, Cronimet, which highlighted a series of environmental and social impacts (Pan-Armenian Environmental Front, 2014). The use of organisational resources from PAEF resulted in significant attention from national and diaspora groups, who were able to persuade the company to improve its social and environmental performance, making the MNE state that "Cronimet's environmental policy is designed to meet high standards as a prerequisite for carrying on 
business in a sustainable society and the protection of life, health and the environment". As the mayor of Kajaran later stated: "the work at [the mine] is hazardous; therefore, people are getting additional privileges for performing certain works; for example, it was stated in the law: "the dusty, underground works were dangerous for health and resulting in cardiopulmonary arrest, silicosis disease. There are employees in Cronimet who are getting special food, bonuses to salaries, retirement benefits". While the CofP was reluctant to commit its own resources against the MNE, it benefited from partnering with the CofI, in this case improving conditions for mine workers.

\subsection{CofP supports the project against the CofI}

The town of Agarak hosts the extraction plant for the GeoProMining (GPM) gold mining project located in Zod, a few hundred kilometres away. The town is impacted by the dust raised when crushing ore and by the chemicals used in the process of extracting gold. The CofP has witnessed the negative impact associated with having the plant in close proximity to where they live and could easily identify areas where they felt a direct influence. For example, on the health condition brought on by mining pollution:

\footnotetext{
"The birds were sitting on polluted water and dying: most probably that was conditioned by the heavy metals, which had a very negative impact on health. Tumours are a widely spread disease in Agarak village. It had a massive spread and there were cancer cases detected involving one, three, six year old children. In Agarak village, the health diagnosis of the residents would be an even higher amount of health deterioration and many of GPM's employees couldn't have children as a result of the company's activities. The absence of proper cleaning procedures of toxic substances affected generations. Especially during recent years, the negative impact had increased (interview, Agarak)."
}

At the same time, the communities realised the interconnectedness with the plant and, to some extent, regarded their faith as a community to be intertwined: "from economical perspectives, the company had a comparably higher positive impact on the community, since the company hired around 80 to 100 employees from Agarak village. If the Zod factory was closed, 100 families would be unemployed (interview, Agarak)". However, being heavily impacted by mining operations does not necessarily mean that CofPs welcome CofIs to represent them, as from another villager: "the citizens of Yerevan have no idea of village life (interview, Agarak)". Villagers were hesitant to demonstrate their resistance to the mining project too openly or to be seen as partnering with CofI. One thought that there should be "big demonstrations [by NGO] against the construction of processing facilities in the territory of tailings, but in fact nothing happened (interview, Agarak)". One of the CofIs also witnessed being asked to leave some of the villages in which they had been protesting as CofP became increasingly hostile. This was possible, because these villages stood to lose much if the CofI was actually successful in ending the mining project. One of the interviewees was working as a teacher in the local school, and she remembered earning a 7,000-AMD monthly net salary, while current teachers' monthly net salary was 70,000 AMD: consequently, their salaries had increased tenfold (interview, Agarak). 


\subsection{CofP accepts the impact}

The incident with dust pollution in the village of Teghut escalated, and national media got involved under the headline "Teghut mine security beat up local villagers: residents block road in protest" (Paremuzyan, 2012), and two national environmental NGOs, ecolur and save Teghut (CofI), called for political interference. The two committed resources that expanded and escalated the issue to include the event in the village and also the legal basis on which the mine operated, questioning the validity of their environmental assessment report. At this point, the conflict with the CofP in Teghut was resolved:

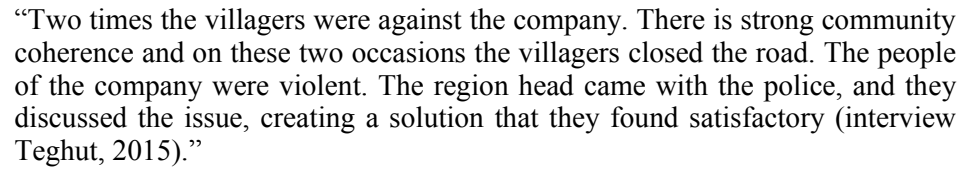
coherence and on these two occasions the villagers closed the road. The people of the company were violent. The region head came with the police, and they discussed the issue, creating a solution that they found satisfactory (interview Teghut, 2015)."

However, CofI continued to commit resources but without the support and resources of the CofP, making claims against the vallex group for not creating a comprehensive environmental assessment report, violating numerous environmental regulations and the rights of CofP members. The CofI claimed: "people from Teghut can't even go to their sanctuary place [a small religious site inside the mine area, they can't even access this place. This is especially important to the people from this village as they relate to the trees and identify with nature (interview save Teghut, 2016)". However, without the CofP either actively supporting or partnering with the CofI, financial, political or cultural stakeholders were inclined not to get involved in the issue, as expressed by one NGO: "if the activists do not do anything, they don't protest (interview, save Teghut)". And as stated by the CEO of PensionDanmark, one of the major investors in the Teghut project: "we are naturally delighted to be able to enter into this agreement, which will increase Danish exports [...] a project that is setting new standards for mining in Armenia (PensionDanmark, 2013)". While there were more attempts by the CofI to raise political and cultural risks, none of these to date has been realised.

In summary, the CofP stands to gain significantly from being geographically close to a mining project in the form of jobs, higher income, improved living standards and access to different forms of welfare facility. As the communities increasingly become aware of the negative consequences that the mining project has on health, safety and socioeconomic development, they realise that, despite these notable drawbacks, their future economic welfare depends on the existence of the mine. Hence, they do not commit resources at a level that could endanger the project so that the MNE would be forced to take any serious mitigating action.

\section{Risk management practices as allocation of resources}

The mining MNE's risk management practice is centred on ensuring that CofPs do not commit resources themselves or partner with CofIs, which can result in the creation of financial, political or cultural risks. The mining MNE can make the community less inclined to commit these resources by making them either directly or indirectly reliant on their investment through the creation of jobs or local socioeconomic development, as 
seen in both Agarak and Kajaran. When, at a later stage, the negative effects of mining activities become evident, and the members of the community of place start to experience health issues, or the local environment starts to suffer, the perceived cost of terminating the project becomes too high, even to a degree where CofP, despite severe environmental problems, supports the continuation of the mining project against CofI.

The mining MNEs' risk management practice also reflects this pattern, as resources to the CofP are more salient in the explorative or early production phases of the project. Here, we found that the MNE primarily allocated resources in the initial phases of the project, when most of the physical changes were still in the planning or early construction phases. For example, when the vallex group's mine was still in the planning and construction phase, "the company conducted quarterly meetings and discussions with the members of the community" (interview, Teghut villager); and, from the MNE side, "consultation started at a very early stage eight years before construction when it was just a draft impact assessment, and when the project went into the development stage we had several stakeholder meetings (interview, vallex mining)". For other projects that were yet to go into production, there were also frequent consultations with CofI, even very critical ones who did not support mining in the country at all.

\footnotetext{
"The NGOs here are extremely aggressive, and they are more considered as activists than anything else. The greatest example is that the day before yesterday we had a meeting organised by NGOs and one of them stood up and said that if I knew that Lydian International was here, I would not have come (interview, Lydian International).
}

For these mining MNEs, it was imperative that their communication was perceived as open and transparent, and one of the ways this could be achieved was to be present and visible in the public arena. This type of community engagement project took on different forms, ranging from philanthropy directed at sports events and scholarships for universities to building infrastructure and renovating public buildings. For example, in Teghut, where the mine is in the early stages of production, "the renovation of roads, the quality of electricity and telecommunication improved due to the financial support of vallex mining", and in Shnogh, another town some five kilometres away from the same mine, "the company renovated the internal and external water lines and sponsored the establishment of the local dance group, repaired the water network - the network hadn't been serviced for a long time - and they built the water irrigation system". The mining executives confirmed that their companies allocated funds for different community development projects: "we built the gas pipeline and improved the irrigation system. Therefore, infrastructure and access wise, they were better off (interview, vallex)".

Mining MNEs, who had been operating for some time, communicated less in the public sphere and prioritised their efforts at targeting specific stakeholders, such as village heads and government officials. For example, in Kajaran, where the mayor is the primary source of information to and from the MNE (Cronimet) "since the company started its operations in 2006, at that time, there had been conducted both public hearings and meetings with community members (Kajaran, mayor)". As time progressed, however, the meetings became less frequent, and an increasing number of decisions were cleared between the mayor and the mining MNE before any announcements. "During city council meetings, the company administration mandatorily discussed and agreed on some questions with the mayor of Kajaran city" (interview, Kajaran), indicating that most, if not all, major issues were resolved before the public hearings took place. When visiting 
Agarak village, where a gold extraction plant is located in central Armenia, a village head claimed that "in 2012, GPM Gold Company promised to provide a bus to Agarak village, but since then nothing had been provided". He further explained how the relationship had deteriorated:

\begin{abstract}
"The emission cleaning procedure has been poorly performed during recent years; during Soviet times, there was high consistency and tonnes of bleach were used to clean and neutralise the cyanide ingredient used in gold production. But currently the company is owned by a foreign organisation, and they have neglected the proper cleaning processes (interview, Agarak)."
\end{abstract}

According to the villagers, this has resulted in sterile employee practices, sick children and cases of heavy metal poisoning, which the MNE has ignored. The MNE's engagement with the community has been very limited, and investments seem to be going slower, following their belief that "GPM didn't provide significant support and several times the municipality applied to the company, but didn't receive any help".

The MNE's allocation of communicative and physical resources aimed at the CofP follows a pattern where engagement is high in the initial phases (exploration and early production) but is then significantly scaled down as the project matures. As the examples used here show, both vallex and Lydian International had invested in projects that directly affected the CofP in their area, while companies like GeoProMining and Cronimet had significantly scaled down both investments and consultations.

\section{Conclusions and discussions}

This paper has analysed how community risk management is practised by mining MNEs in Armenia. We conceptualised communities as CofPs, consisting of villages and towns geographically close to the mining MNEs' activities, and CofIs as outsiders, like NGOs and other civil society organisations that have an interest in mining operations. We analysed community risk as materialising through the allocation of resources from the CofP, either alone or in partnership with CofI, which in both cases aimed at motivating financial, political or cultural actors to take actions that influence business continuity.

We found that community risk management is practised by the mining MNEs through allocation of both communicative and physical resources towards the CofP. This can be done through community consultations and town hall meetings as well as physical investments in infrastructure, kindergartens or other services. We argue that the response from a community risk perspective can fall within four domains. Community risk can materialise if CofP commits its own resources or forms a partnership with a CofI that then commits its resources, in both cases, directed towards financial, political or cultural actors. Community risk is, in both cases, increased, as decisions to apply resources intensify risks to the mining MNE. When a CofP supports the mining project against the CofI, or when a CofP remains passive despite the impact of the mining project, the risk management practices of the mining MNE are successful in decreasing community risk.

However, we found a difference in the effect of the resource allocation between CofP and CofI when it came to their ability to initiate actions from financial, political and cultural actors. When CofPs committed resources alone, they seemed unable to activate actors outside their geographical region; while their claims were valid, it was only when they partnered with the CofI that the mining MNE took action to mitigate risk. While the 
CofP and its specific grievance with the mining MNE was more marginalised when engaging in this partnership, it created more awareness in wider circles of the challenges that were faced. We therefore find that mining MNE community risk management practice targets CofP, with the aim of preventing them from partnering with CofI, who have the resources to activate financial, political and cultural actors that are perceived as posing a higher risk to business continuity. This finding is further supported by our analysis of instances where the community was either passive, thereby accepting the impact that the mine had on the community, or when they actively opposed CofI in interfering in the relationship despite very severe impacts from the local mine. While the Cofl could commit resources that raised risks without the support of the CofP, their argument would have less legitimacy with the aforementioned actors and thus possibly less success in changing mining MNE behaviour.

This risk management practice of preventing CofPs from partnering with CofI or encouraging them to remain passive was further substantiated. We found that, in the exploration or early stages of production, mining MNEs communicated more frequently and invested more, while, as the project matured, these activities were scaled back significantly. However, while we thought that the resource commitment of the mining MNE and the level of community risk would be proportional this did not seem to be the case. Our interpretation is that, as time passes, the CofP becomes increasingly reliant on the jobs being created, the infrastructure and institutions being supported, like roads, and educational facilities or scholarships, and while these are scaled back, it does not significantly reduce the risk that it will commit resources against the mining MNE and, in some cases, even support the project against outside interference. This finding is in-line with other research that finds that communities recognise the short-term advantages that come with these types of projects and the increase in jobs, as well as access to basic welfare benefits but also that these come with a trade-off in the form of increases in crime and disruption of family patterns (Dana et al., 2009; Horowitz, 2010; Prno and Slocombe, 2014). This understanding of mining MNE risk management practice was further substantiated by the finding that CofI did not play a significant role in the allocation of mining MNE resources. Rather, these groups were, to a large extent, ignored when it came to communication, aside from invitations to stakeholder consultation meetings. Underlined by the aforementioned statement from the CEO of Lydian International that described them as more of a nuisance than an actual threat, the literature nevertheless places NGOs and civil society actors as key stakeholders when it comes to risk management. We interpret the lack of focus on CofI as an indication that the MNE knew from previous experiences that, by following a CofP-focused risk management practice, these diverse and possibly more complex stakeholders could be largely ignored.

\section{Revised model}

The findings and conclusions have prompted the need to revise the initial model (Figure 2). The new model adds and revises two elements, namely time, when it comes to resource allocation, and the role of CofI. 
Figure 2 Revised model of MNE community risk management based on findings (see online version for colours)

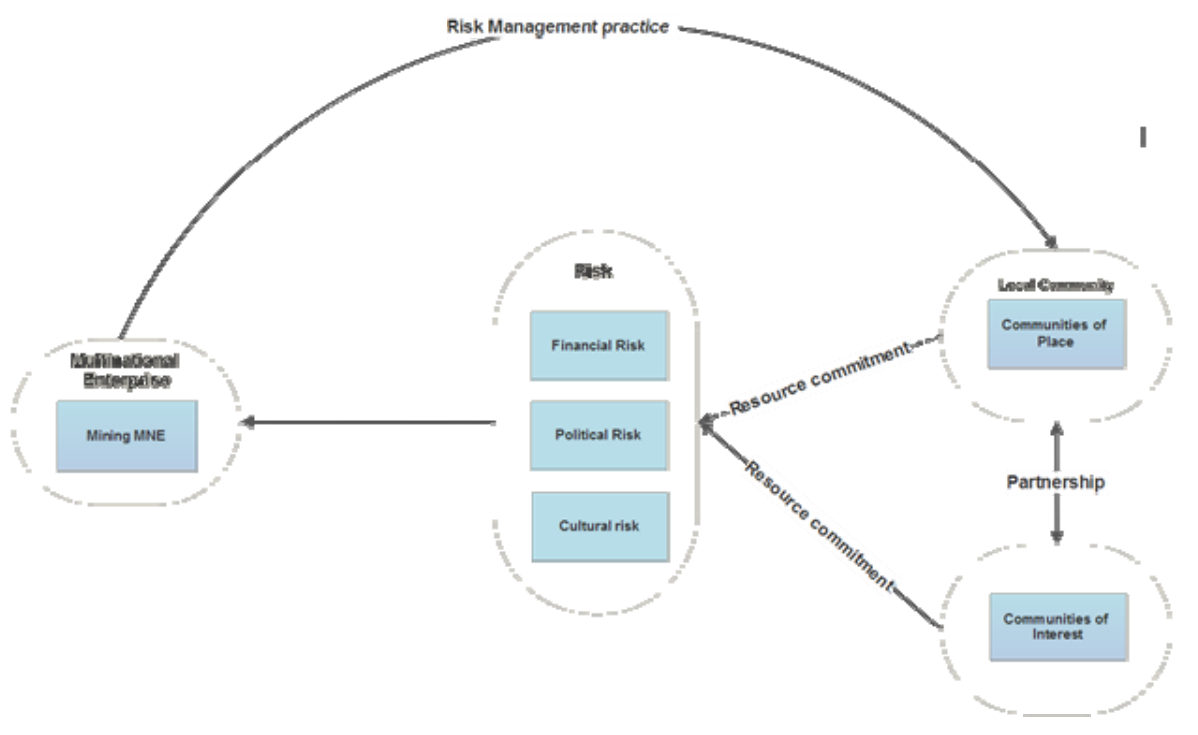

First, the element of time was originally thought to be a major factor in reducing liability of outsidership, as it allowed the MNE to learn how to navigate in the local market. However, the MNE did not focus on acquiring knowledge about the local culture, customs or other unique characteristics in the local context. The risk management practice focused on committing resources to meet generic local demands, such as access to basic services and improvements to local institutions, neither of which was specifically tailored to the local context. For the mining MNEs, this carried with it several advantages: it did not have to allocate resources to building new capabilities, which might not be transferable to another setting, and it could focus on activities that were of direct benefit to its own operations: for example, it could invest in infrastructures, like new roads, gasification and electricity, which would be required when the mine was constructed, and investments in kindergartens and schools would ensure that there would be access to the local workforce. Furthermore, as the project matured, it was possible for the mining MNE to scale down some of these activities significantly without being subjected to community risk. This was due to the reliance of the CofP on some of these generic services that, even though they became very marginal, sustained the community's economic and cultural life. The model was thus changed to reflect the limited resources that the community of place could commit to expose the mining MNE to financial, political and cultural risks (illustrated by a dotted line).

The second change to the model was in the role of CofIs, who were believed to be a significant stakeholder group, as they could expose the mining MNE to financial, political and cultural risks and had the resources to do so. If the CofP and CofI partnered, it lent legitimacy to the CofI when committing resources that exposed the mining MNE to risk. This was also evident in the analysis, as CofI were largely ignored, with a few expectations, when it came to communication and public engagement activities. Collaboration between the two community groups could pose a significant and 
resource-intensive risk, which can explain why the efforts of the MNEs focus on preventing CofPs from forming partnerships with CofIs. In this way, the objective of mining MNEs' risk management practice is to reduce community risk by committing resources to the CofP for as long as there is a possibility that they might form lasting partnerships with CofI. An arrow in the revised model illustrates the existence of a partnership between the two.

\section{Contributions}

The contribution of this paper is threefold. First, it contributes to the MNE risk management literature by highlighting the importance of CofP in risk management practice. The MNE risk management literature has traditionally investigated uncertainties on a national or regional level, which fails to provide valuable insights into how risk management is practised on a local community level. By conceptualising community risk as a unique source of risk that, if left unmanaged, can evolve into financial, political and/or cultural risks, the latter gains importance when it comes to understanding the early warning signs of emerging uncertainties.

Second, the paper contributes by differentiating between CofP and CofI as sources of risk, in contrast to the MNE risk management literature that does not differentiate between the two groups. By focusing on CofPs, which are impacted on a daily basis but have few resources available to them, and CofIs, which have a clear objective of creating uncertainty and have resources, it is possible to understand how the relationship between the two groups can affect community risk exposure. CofP can be both a threat and a resource that the MNE can use in its risk management practice for mitigation purposes. Finally, the paper emphasises the importance of time in how the MNE's relationship with the CofP evolves, which has previously been largely neglected. While time was not part of the initial scope of the paper, its role is an important finding in that MNE risk management practice varies as the relationship between the MNE and community of place matures, prompting more research into how the passage of time in the relationship can affect overall risk exposure, especially when it comes to an industry like mining, where the impact on the community of place increases over the project lifespan.

\section{References}

Anderson, C. (2014) 'Mining and the fall and rise of poverty in southern West Virginia', The Extractive Industries and Society, Vol. 1, No. 1, pp.2-3.

Archer, M. (2010) 'Routine, reflexivity, and realism', Sociological Theory, Vol. 28, No. 3, pp. $272-303$.

Bebbingtion, A., Hinojosa, L., Bebbingtion, D.H., Burneo, M.L. and Warnaars, X. (2008) 'Contention and ambiguity: mining and the possibilities of development', Development and Change, Vol. 39, No. 6, pp.887-914.

Bekaert, G., Harvey, C.R., Lundblad, C.T. and Siegel, S. (2014) 'Political risks spread', Journal of International Business Studies, Vol. 45, No. 4, pp.471-483.

Birt, J., Rankin, M. and Song, C.L. (2013) 'Derivatives use and financial instrument disclosure in the extractives industry', Accounting and Finance, Vol. 53, No. 1, pp.55-83.

Boddewyn, J.J. and Brewer, T.L. (1994) 'International-business political behaviour: new theoretical directions', Academy of Management Review, Vol. 19, No. 1, pp.119-143. 
Bond, A.R. and Levine, R.M. (1997) 'Development of the copper and molybdenum industries and the Armenian economy', Post-Soviet Geography and Economics, Vol. 38, No. 2, pp.105-120.

Burgess, A. (2015) Social construction of Risk in the Sage Handbook of Risk Communication, Sage Publications, Inc., Thousands Oaks.

Business for Social Responsibility (BSR) (2003) The Social License to Operate [online] http://www.sdsg.org/wp-content/uploads/2013/04/file_BSR_Social_License_to_ Operate.pdf (accessed 26 October 2017).

Calvano, L. (2008) 'Multinational corporations and local communities: a critical analysis of conflict', Journal of Business Ethics, Vol. 82, No. 4, pp.793-805.

Canabal, A. and White, G.O. (2008) 'Entry mode research: past and future', International Business Review, Vol. 17, No. 3, pp.267-284.

Christoffersen, P. (2003) Elements of Financial Risk Management, Elsevier Science, Oxford.

Cheshire, L. (2010) 'A corporate responsibility? The constitution of fly-in, fly-out mining companies as governance partners in remote, mine-affected localities', Journal of Rural Studies, Vol. 26, No. 1, pp.12-20.

Dana, L-P., Anderson, R.B. and Meis-Mason, A. (2009) 'A study of the impact of oil and gas development on the dene first nations of the Sahtu (Great Bear Lake) region of the Canadian Northwest Territories (NWT)', Journal of Enterprising Communities: People and Places in the Global Economy, Vol. 3, No. 1, pp.94-117.

Dana, L-P. and Anderson, R.B. (2014) 'Mining and communities in the Arctic: lessons from Bake Lake, Canada', International Journal Entrepreneurship and Small Business, Vol. 22, No. 3, pp.343-361.

Dana, L-P. and Dana, T.E. (2005) 'Expanding the scope of methodologies used in entrepreneurship research', International Journal Entrepreneurship and Small Business, Vol. 2, No. 1, pp.79-88.

Dana, L-P. and Demuz, H. (2015) 'Qualitative research revisited: epistemology of a comprehensive approach', International Journal Entrepreneurship and Small Business, Vol. 26, No. 2, pp.155-170.

Dana, L-P., Mason A.M. and Anderson R.B. (2009) 'A study of enterprise in Rankin Inlet, Nunavut: where subsistence self-employment meets formal entrepreneurship', International Journal Entrepreneurship and Small Business, Vol. 7, No. 1, pp.1-23.

Davis, R. and Franks, D.M. (2014) Costs of Company-Community Conflict in the Extractive Sector, Corporate Social Responsibility Initiative Report No. 66, Harvard Kennedy School, Cambridge, MA.

DiMaggio, P.J. and Powell, W.W. (1983) 'The iron cage revisited: institutional isomorphism and collective rationality in organisational fields', American Sociological Review, Vol. 48, No. 2, pp.147-160.

Eisenhardt, K.M. (1989) 'Building theories from case study research', The Academy of Management Review, Vol. 14, No. 4, pp.532-550.

Elder-Vass, D. (2010) The Causal Power of Social Structures, Cambridge University Press, UK, Cambridge.

Erb, C.B., Harvey, C.R. and Viskanta, T.E. (1996) 'Political risk, economic risk, and financial risk', Financial Analyst Journal, Vol. 52, No. 6, pp.29-46.

Feinberg, S.E. and Gupta, A.K. (2009) 'MNC subsidiaries and country risk: internalisation as a safeguard against weak external institutions', Academy of Management Journal, Vol. 52, No. 2, pp.381-399.

Figueira-de-Lemos, F., Johanson, J. and Vahlne, J. (2011) 'Risk management in the internationalisation process of the firm: a note on the Uppsala model', Journal of World Business, Vol. 46, No. 2, pp.143-153.

Flick, U. (2009) An Introduction to Qualitative Methods, 4th ed., Sage, London. 
Franks, D.M. and Cohen, T. (2012) 'Social license in design: constructive technology assessment within research and development institution', Technological Forecasting \& Social Change, Vol. 79, No. 7, pp.1229-1240.

Franks, D.M., Davis, R., Bebbington, A.J., Ali, S.H., Kemp, D. and Scurrah, M. (2014) 'Conflicts translate environmental and social risk into business costs', PNAS, Vol. 111, No. 21, pp.7576-7581.

Ghoshal, S. (1987) 'Global strategy: an organizing framework', Strategic Management Journal, Vol. 8, No. 5, pp.425-440.

Gifford, B. and Kestler, A. (2008) 'Towards a theory of local legitimacy by MNEs in developing nations: Newmont mining and health sustainable development in Peru', Journal of International Management, Vol. 14, No. 4, pp.340-352.

Graetz, G. and Franks, D.M. (2015) 'Conceptualising social risk and business risk associated with private sector development projects', Journal of Risk Research, Vol. 19, No. 5, pp.581-607.

Hagigi, M. and Sivakumar, K. (2009) 'Managing diverse risks: an integrated framework', Journal of International Management, Vol. 15, No. 3, pp.286-295.

Hilson, G. and McQuilken, J. (2014) 'Four decades of support for artisanal and small-scale mining in sub-Saharan Africa: a critical review', The Extractive Industries and Society, Vol. 1, pp.104-118.

Holterman, D. (2014) 'The biopolitical war for life: extractivism and the Ugandan oil state', The Extractives and Society, Vol. 1, pp.28-37.

Horowitz, L.S. (2010) 'Twenty years is yesterday': science, multinational mining, and the political ecology of trust in New Caledonia', Geoforum, Vol. 41, No. 4, pp.617-626.

International Council on Mining and Metals (ICMM) (2014) Oxford Policy Management [online] http://www.icmm.com/national-economies (accessed 26 October 2017).

International Council on Mining and Metals (ICMM) (2015) Indigenous People and Mining, 2nd ed., International Council on Mining and Metals Raw Materials Group, London.

Investment Guide (2013) Investment Guide: Armenia 2013, The Ministry of Economy of the Republic of Armenia, Armenia.

Johanson, J. and Vahlne, J.E. (2009) 'The Uppsala internationalisation process model revisited: from liability of foreignness to liability of outsidership', Journal of International Business Studies, Vol. 40, No. 9, pp.1411-1431.

Kadenic, M.D. (2015) 'Socioeconomic value creation and the role of local participation in large-scale mining projects in the Arctic', The Extractive Industries and Society, Vol. 2, pp.562-571.

Kemp, D. and Owen, J.R. (2013) 'Community relations and mining: core to business but not 'core business', Resource Policy, Vol. 38, No. 4, pp.523-531.

Kemp, D., Worden, S. and Owen, J.R. (2016) 'Differentiated social risk: rebound dynamics and sustainability performance in mining', Resource Policy, Vol. 50, pp.19-26.

Kraemer, R. and van Tulder, R. (2009) 'Internationalization of TNCs from the extractive industries: a literature review', Transnational Corporation, Vol. 18, No. 1, pp.137-156.

Lodh, S. and Nandy, M. (2008) 'Exploring country risk: MNCs mindset', The ICFAI Journal of International Business, Vol. 3, No. 2, pp.24-35.

Lundan, S. (2014) Transnational Corporations and Transnational Governance: the Cost of Crossing Borders in the Global Economy, Palgrave Macmillan, New York.

Lynch, M. (2002) Mining in World History, Reaktion Books, London.

Miller, K.D. (1992) 'A framework for integrated risk management in international business', Journal of International Business Studies, Vol. 23, No. 2, pp.311-331.

Miller, R. and Lessard, D. (2001) 'Understanding and managing risks in large engineering projects', Int. J. Proj. Manag., Vol. 19, No. 8, pp.437-443. 
Missens, R., Dana, L-P. and Anderson, R. (2007) 'Aboriginal partnerships in Canada: focus on the Diavik Diamond Mine', Journal of Enterprising Communities: People and Places in the Global Economy, Vol. 1, No. 1, pp.54-76.

Morris, M., Kaplinsky, R. and Kaplan, D. (2012) One Thing Leads to Another: Promoting Industrialisation by Making the Most of the Commodity Boom in Sub-Sharan Africa, Self-published, University of Cape Town.

Nyame, F.K. and Grant, J.A. (2014) 'The political economy of transitory mining in Ghana: understanding the trajectories, triumphs, and tribulations of artisanal and small-scale operators', The Extractive Industries and Society, Vol. 1, No. 1, pp.75-85.

O'Fairchellaigh, C. (2003) 'Implementing agreements between indigenous peoples and resource developers in Australia and Canada', Aboriginal Politics and Public Sector Management, Research Paper No. 13.

Pan-Armenian Environmental Front (2014 Armenians' Broken Backbone [online] http://www. armecofront.net (accessed 26 October 2017).

Paremuzyan, L. (2012) Teghout Mine Security Beat up Local Villagers: Residents Block road in Protest [online] http://hetq.am/eng/news/13158/teghout-mine-security-beat-up-local-villagersresident-block-road-in-protest.html (accessed 26 October 2017).

Park, B.I., Chidlow, A. and Choi, J. (2014) 'Corporate social responsibility: stakeholders' effect on MNEs' activities', International Business Review, Vol. 23, No. 5, pp.966-980.

PensionDanmark (2013) EKF and Pension Denmark Secure Financing of Large Orders for FLSmidth [online] https://www.pension.dk/en/english/About-PensionDenmark/News/PDnews/EKF-and-PensionDenmark-secure-financing-of-large-orders-for-FLSmidth/ (accessed 17 May 2015).

Perri (2005) 'What's in a frame? Social organization, risk perception and the sociology of knowledge', Journal of Risk Research, Vol. 8, No. 2, pp.91-118.

Petrosyan, V., Orlova, A., Dunlap, C.E., Babayan, E., Farfel, M. and von Braun, M. (2004) 'Lead in residential soil and dust in a mining and smelting district in northern Armenia: a pilot study', Environmental Research, Vol. 94, No. 3, pp.297-308.

Power, M. (2004) 'The risk of everything', Journal of Risk Finance, Vol. 5, No. 3, pp.58-65.

Power, M. (2007) Organised Uncertainty: Designing a World of Risk Management, Oxford University Press, Oxford.

Prno, J. and Slocombe, D.C. (2014) 'A systems-based conceptual framework for assessing the determinants of a social license to operate in the mining industry', Environmental Management, Vol. 53, No. 3, pp.672-689.

Selmier, W.T., Newenham-Kahindi, A. and Hoon Ch, C. (2015) 'Understanding the world of relationships: language as an essential tool to manage CSR in communities of place', Journal of International Business Studies, Vol. 46, No. 2, pp.153-179.

Simon, J.D. (1984) 'A theoretical perspective on political risk', Journal of International Business Studies, Vol. 15, No. 3, pp.123-143.

Stoffle, R. and Minnis, J. (2008) 'Resilience at risk: epistemological and social construction barriers to risk communication', Journal of Risk Research, Vol. 11, Nos. 1-2, pp.55-68.

Tatoglu, E., Bayraktar, E., Sahadev, S., Demirbag, M. and Glaister, K.W. (2013) 'Determinants of voluntary environmental management practices by MNE subsidiaries', Journal of World Business, Vol. 49, No. 4, pp.536-548.

The Economist (2015) Country Report - Armenia, Economist Intelligence Unit, 4 April, London.

Yin, R.K. (1994) Case Study Research: Design and Methods, 2nd ed., Sage, London.

Zaheer, S. (1995) 'Overcoming the liability of foreignness', Academy of Management Journal, Vol. 38, No. 2, pp.341-363. 